\title{
Bureaucratic Behavior towards Public Management: The Study of Health Services Free in South Sulawesi Province, Indonesia
}

\author{
Jamaluddin Ahmad $^{1} \&$ Erfina $^{1}$ \\ ${ }^{1}$ Department of Public Administration, Stisip Muhammadiyah Rappang, South Sulawesi, Indonesia \\ Correspondence: Jamaluddin Ahmad, Department of Public Administration, Stisip Muhammadiyah Rappang, \\ Jalan Angkatan 45 No. 1A Lt. Salo Rappang, Po Box 91651, South Sulawesi, Indonesia. Email: \\ jahmadlado@yahoo.co.id
}

Received: April 3, 2017

Accepted: April 6, 2017

Online Published: April 19, 2017

doi:10.5539/res.v9n2p170

URL: http://doi.org/10.5539/res.v9n2p170

\begin{abstract}
Public services in Indonesia in the health sector has not been optimal characterized by complexity of the procedures that experienced, public complaints are still high, and the cost of services is less transparent. The government through bureaucratic reform 2010-2025 Grand Design have established guidelines for the implementation of public services to the world-class public management. The ultimate goal is to improve public services is good and right, improve the quality of policy-making and decision-making, to prevent misuse of authority, and improve resource efficiency. Type of bureaucratic behavior will determine the achievement of bureaucratic reform. Facts and data showing through phenomenology. The data collected with in-depth interviews, observation, and documentation on health services in South Sulawesi indicates that the type of behavior of the bureaucracy in order to realize the reform of the bureaucracy is still in the category of politicians from the four types discussed include the type of employee career, type of politician, professional type, and the type of missionary.
\end{abstract}

Keywords: type of behavior bureaucracy, public management, health services free

\section{Introduction}

\subsection{Bureaucratic Reform}

Government functions as a public servant. Theoretically at least three major functions to be executed by the government regardless of its level, namely the public service function, development function, and protection function. The most important of these three functions is that the government can manage its functions in order to produce goods and services are economical, effective, efficient, and accountable to all the people who need them. In addition, the government is required to apply the principle of equity in carrying out these functions. This means that government services should not be administered in a discriminatory manner. Services are provided regardless of status, rank, class of society and all citizens have equal rights on such services in accordance with applicable regulations. Public service motivation and identifies a typology of motives associated with public service that includes rational, norm-based, and affective motives (Perry, 1990).

Therefore, the Indonesian government through 2015-2025 bureaucratic Reform Design Grand have established guidelines for the implementation of public services to the world-class public management. The ultimate goal is to improve public services is good and right, improve the quality of policy-making and decision-making, to prevent misuse of authority, and improve resource efficiency.

Therefore, one form of public service Indonesian government, which has been implemented by the government of South Sulawesi is a free health care for the needy held since July 2008. This free service includes the service delivery and basic health services. Free health care network includes Community Health Center and referral to the third grade at government hospitals and the use of generic drugs. To get a free health service, the public quite show the card or card showing the identity (ID) card or family, all fees will be charged to local governments. Meanwhile, if people require further treatment, the hospital will be referred to the local level.

The facts and data available, free health policy of the interesting discussion with Indonesian government policy after the policy of reform bureaucracy towards a world-class public management are disseminated through the Ministry of Administrative Reform and Bureaucratic Reform. What and how the local government of South 
Sulawesi implementing bureaucratic reform towards a world-class public management, in particular on free healthcare interesting to discuss. This aims to provide an overview and a detailed analysis of the implementation of the reform of the bureaucracy towards a world-class public management.

Once the importance of bureaucratic reform in order to establish a world-class public management. The theory's most prominent advocate, Max Weber, proposed a "bureaucratic form" of structure, which he thought would work for all organizations. Weber's idea bureaucracy was, logical, rational and efficient. He made the naive assumption that one structure would work best for all organizations (Robbins, 1993). Behavioral approach meant as a study investigating the effect of which is owned by an individual, group, and organizational structure of the behavior to improve the effectiveness of an organization.

\subsection{Reform of the Bureaucracy towards a World-Class Public Management}

The importance of health services in South Sulawesi Province become a study of bureaucratic reform towards a world-class public management for South Sulawesi Province is the gateway to eastern Indonesia. South Sulawesi Provincial often be a reference to provinces in eastern Indonesia to implement the policies of the central government. Particularly policy basic public services such as free healthcare and free education. Thus, the importance of the reform of the bureaucracy towards a world-class public management will be interpreted each of the provinces, especially the giving of the functions of government that have been described previously.

\subsection{Overview of the Literature on Behavior Bureaucracy and Public Management}

To understand "behavior bureaucracy" this study employs a model from the field of social psychology, the Theory of Planned Behavior (TPB). This model, traditionally used to explain and predict individual volitional behaviors, provides a useful framework for determining the factors important to bureaucratic behavior, and it provides a mechanism for testing the various propositions about bureaucratic behavior previously identified. The TPB, which is represented graphically in figure, postulates that an individual's behavior results first from the intention to perform a given behavior. This intention is in turn caused by three central factors: (1) attitudes toward the behavior; (2) subjective norms, or the perceptions an individual has about the normative beliefs of others related to the behavior; and (3) perceived behavioral controls, or the factors believed to be constraining or facilitating an individual's behavior. In other words, the TPB will be used to analyze the relative effect of attitudes, subjective norms, and perceived behavioral controls on the behavior of Army bureaucrats, specifically their behavior with respect to the elimination of mil specs and standards - and will help to determine whether self-interest, rules, or some combination can actually be linked to reform behavior (Schmidt, 2000).

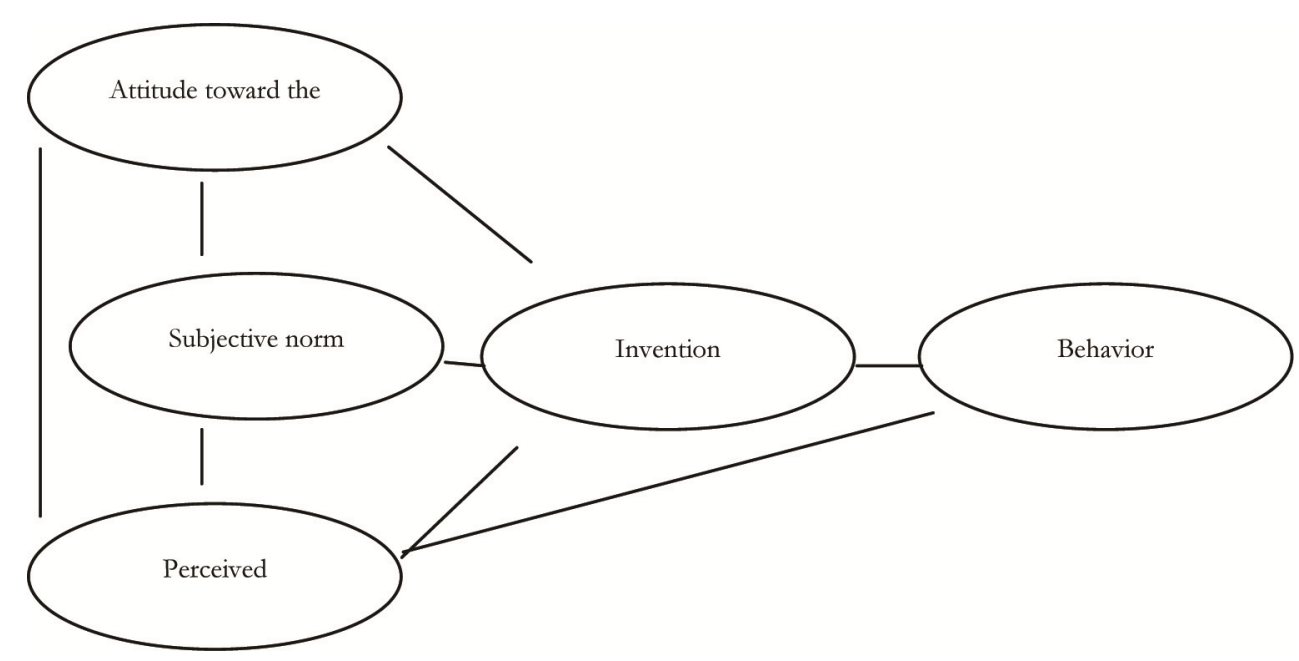

Figure 1. The theory of planned behavior

As in the original theory of reasoned action, a central factor in the theory of planned behavior is the individual's intention to perform a given behavior. Intentions are assumed to capture the motivational factors that influence a behavior; they are indications of how hard people are willing to try, of how much of an effort they are planning to exert, in order to perform the behavior. As a general rule, the stronger the intention to engage in a behavior, the more likely should be its performance. It should be clear, however, that a behavioral intention can expression 
in behavior only if the behavior in question is under volitional control if the person can decide at will to perform or not perform the behavior. As a general rule, the stronger the intention to engage in a behavior, the more likely should be its performance. Although some behaviors may in fact meet this requirement quite well, the performance of most depends at least to some degree on such non motivational factors as availability of requisite opportunities and resources (Ajzen, 1991).

The control of "Street-level bureaucrats" raises a particularly interesting and thorny set of issues for scholars interested in bureaucratic control and policy implementation (Winter, 2002, August). Personal interactions between clients and street-level bureaucrats are significant in explaining why street-level bureaucrats behave as they do (Keiser, 2010).

A key approach to the study of discretion is Lipsky's "Street-level bureaucrats" theory, in this perspective has re-emerged as a significant point of debate in the analysis of the impact of managerial reforms of public services. An important aspect of these reform has been the attempt to curtail professional discretion in the organization and delivery of services (Evans, 2016).

Bureaucrats might never think to move to another job, but if there is a chance, he will use it. However, we analyze the types of bureaucratic behavior, must not be denied the strengths and weaknesses of each. It is important to know, as long as the bureaucrat to do, he should carry out their duties by the criteria that have expressed. Thus, the type of behavior is what a lot of coloring process of public policy. As further, proof of the assertion, then for this kind of search conducted through a career employee, the type of politician, professional type, and the type of missionary. These guys will not be likely to be found separately, so it concluded that the emerging eclectic.

Organizational research present two conflicting views of the human, or attitudinal, outcome of bureaucracy. According to the negative view, the bureaucratic form of organization stifles creativity, fosters dissatisfaction, and de-motivates employees. According to the positive view, it provides needed guidance and clarifies responsibilities, thereby easing, role stress and helping individuals be and feel more effective (Adler, 1996). The two conflicting view relies heavily on behavior bureaucracy.

For Example, the relationship between bureaucratic structure and innovative behavior is examined by comparing the conditions within the bureaucratic structure with the conditions found by psychologists to be most conducive to individual creativity. The conditions within bureaucracy are found to be determined by a drive for productivity and control, and inappropriate for creativity. Suggestions are made for alterations in bureaucratic structure to increase innovativeness, such as, increased professionalization, a looser and more untidy structure, decentralization, freer communications, project organization when possible, rotation of assignments, greater reliance on group processes, attempts at continual restructuring, modification of the incentive system, and changes in many management practices. It is suggested that bureaucratic organizations are actually evolving in this direction (Thompson, 1965).

For the political type behavior bureaucracy, the efficiency criteria for allocating policy tasks to elected policymakers (politicians) or non elected bureaucrats. Politicians are more efficient for tasks that do not involve too much specific technical ability relative to effort; there is uncertainty about ex post preferences of the public and flexibility is valuable; time inconsistency is not an issue; small but powerful vested interests do not have large stakes in the policy outcome; effective decisions over policies require taking into account policy complementarities and compensating the losers (Alesina, 2007).

For the career type behavior bureaucracy, the traditional lifelong organizational career model no longer remains relevant for many workers, particularly those active in the knowledge economy. Instead these workers are claimed to pursue boundaryless and protean careers (Donelly, 2009). For the mission type behavior bureaucracy, mission-driven government-transforming rules-and-procedures-driven organizations into entities that are clear on their missions and mandates, and have few internal obstacles in the way of accomplishing them (Plastrik, 1997). The bureaucracy is implementing public policy function that works on a structure by considering a variety of options from the environment (Ahmad, 2011).

A "pathology of red tape", it characterized by a pathological propensity for perception, behavioral and managerial style, the problem of knowledge and skills, unlawful acts, behavioral, and their internal situation (Siagian, 1994). While identify pathology arises because the norms and values of the reference law bureaucracy more oriented upwards, which that in the interests of power politics, rather than to the public (Dwiyanto, 2002).

Reinforce the importance of bureaucratic reform in Indonesia leading world-class public management. Reform is to change or make something better than it already is. This reform aimed at societal changes including 
bureaucratic society, in the sense of a change in the direction of progress. There were change or renewal of the two sides, namely changes in the structure and performance changes. Structurally use of structural differentiation as one measure. The performance differences are the behavioral change in the provision of public services. This view based on the likelihood roles increasingly specialized bureaucracy and the division of labor is increasingly sharp and intense in modern society. As for performance, it emphasized as a measure not only the performance of the others or the organization as a whole (Riggs, 1986).

In this sense bureaucratic change is directed at development. Bureaucratic reform is essentially an effort to reform and fundamental changes to the system of governance, especially concerning institutional aspects (structure), management and human resources' personnel.

The sense of reform as an attempt to modify the subject in a bureaucratic system that aims to change the structure, behavior, and the existence or habits that have been long. There were defines reform as a process to modify the process, public bureaucratic procedures and attitudes and behavior of bureaucrats to achieve the effectiveness of bureaucracy and national development goals. Activities reform as equivalent to another of change, improvement or modernization. From this sense, the change of its scope not limited to processes and procedures, but also linked changes in the level of structure and attitude-behavior (the ethics being). Direction to be achieved reforms, among others, the achievement of public services effectively and efficiently. Reforms aimed at correcting and continually renews towards nation building that had been far away, back to the ideals of the proclamation. Bureaucratic reform is necessary that globalization does not marginalize this nation. There were states that three strategies are creating a bureaucracy of good governance is through a behavioral approach, institutional approach, and social approaches. Behavioral approach placed as the main thing, because any other approach would follow (Said, 2007).

At the same concept, the reform of public management is directed towards world class. The Indonesian government launched a reform of the bureaucracy thirteen principles: (1) Basic good behavior of public officials is devotion, intent to manage public services, and support and encourage others who provide public services; (2) Study of difficult obstacles; (3) Reform of the bureaucracy starting from the individual reforms, and would require support levers of change which encourages others to reform themselves; (4) Providing good value realized through the best service; (5) The Minister and the ministry as a public servant and help public services; (6) Senior officials are required to formulate a strategic plan to implement the individual as an official institution's strategic plan; (7) Apparatus professional to be the backbone of bureaucratic reforms; (8) The size of the achievement of the performance is the operational manual activities, such as the use of basic finance; (9) The purpose of bureaucratic reform is the overall improvement that results in improved a great benefit to society; (10) In the legislation there should be no rule double and not a burden on society than as necessary to ensure the rights of individuals and the set of public interest; (11) The Government does not bear its own reforms, many participating partners to improve government performance; (12) Reform of the bureaucracy necessary political support to gain great momentum and resonance; (13) Every person and every group of people assigned to the public sector and the use of state finances must demonstrate its performance results, and shall comply with the legislation.

\section{Method}

This study uses a phenomenological models for the study of a model that describes the meaning of the life experiences of individuals. Phenomenology is defined as a subjective experience and the study of consciousness from the perspective of a person subject. For this purpose there are four data collection techniques in this research, namely: literature review, observation, interviews, and documentation. The data analysis technique is the reduction, presentation and conclusion. The validity of the data required inspection techniques, especially checking the information obtained in the field, based on various documents the results of the free health care and a data field. Test observations confidence by extending, enhancing perseverance, triangulation, negative case analysis and use of reference materials.

\section{Results and Discussion}

\subsection{Basic Behavior Officer Is Devotion}

Act of 1945 mandates that the State Government and aims to promote the general welfare and being smart life of an independent nation, united, sovereign, just and prosperous. One common form of increased welfare to realize good health service. Law on Public Services (Law No. 25/2009) as the basis for improving public services by health care providers on all fronts. 
As with any other Act, Law No. 25 of 2009 sets up a complete how should public service providers acting in accordance with the principles in question. Also does not regulate how the officials and civil servants will behave and motivate yourself to serve. Law on public service, the principles of good governance (good governance), has been the inspiration to build and improve the quality of service to a society free from corruption, collusion and nepotism. Many people who already know the principles and the principles of good governance. But it must be admitted, not everyone implement the principles and principles already knew. Many of the public service providers already understand the principles of good governance, but they fail to provide good public services. Therefore, the State administrators, public officials, civil servants, and any person concerned has not been constituted with devotion to public service and is not obligated to describe the principle and the principle of good service in the form of a detailed work plan and measurable. The work plan with these principles in everyday life has not been implemented by any public service units.

Free health policy that has been declared by the Governor of South Sulawesi since 1 July 2008 could be the locus in understanding the principles of public management reform of the bureaucracy towards world class. "Health care in community health centers should not be paid", a statement from Governor Dr. Syahrul Yasin Limpo. Free health financing is a sharing of the provincial government $40 \%$ and the district/city by $60 \%$. The concept of mandates to local governments or public servant at the local level is to apply the values of service as the noble values of basic health services.

Basic behavior of officials in the form of devotion can be traced in free health care, because starting from the man-agement on duty at the conceptual level to the technical and operational management directly involved. James L. Perry argued that any public administrators need at least three basic skills are conceptual skill, humanity skill, and technical skill. Conceptual skill seen in the ability to create concepts and ideas (Keban, 2008).

Free health care is a result of conceptual skill Governor of South Sulawesi that directly touches people. Free health services also have skill Humanity looks at the ability to interact with others who put forward persuasive to the public. Likewise, free health care has seen Technical skills in the use of medical equipment that is directly applicable in health care units. The third skill in free health care carried out in stages.

Nonetheless, free health care is not yet always run well and successfully, various obstacles found in the field, such as referral issues not well coordinated, budgets are still limited at the district/city, and a legal framework that is used still needs refinement. Specialty referral coordination, for example, each of the service providers to interpret the value of services provided. Referral health services is a process of devolution of authority and responsibility for cases of illness or health problem to health care facilities that have better capabilities. Recognized by Rahmat Latif (Head of the Provincial Health Office of South Sulawesi) that "health care referral should gradually from a community health center, and then to the hospital type $\mathrm{C}$ (hospital regency), next to the hospital type B (hospital region level) and finally to the house pain type A (hospital-level final), the system is still experiencing problems and not well coordinated. Some of the things that made less effective referral system is a long distance, a greater cost, as well as a longer time".

Targets of bureaucratic reforms in the referral system like this would still take time and cost a bit so that the expectations of realization of the basic behavior of officials is not implemented optimally devotion. Society as the recipient of the service will lose patience so short cuts to pay for treatment and medicines they need.

\subsection{Learning from Difficult Hurdle}

Various kinds of difficult obstacles faced by the people in free health care. One of the barriers frequently encountered is rejection. Often rejection was not visible, because the parties are not voiced his opposition reject direct or even openly. Revan case Adiyaksa Andi Amir new one and a half year-old died on June 26, 2013 due to illness vomiting and defecation. He died after being turned treated at Southwestern General Hospital, Hospital Wahidin Sudiro Husodo, Ibn Sina Hospital, and the Awal Bros Hospital. According to Revan's parents "rejection of the four hospitals that because Revan uses the health insurance area, while the reason for the hospital refused because the room was full treatment".

The case was one of the important lessons of bureaucratic reform should learn from difficult barriers, particularly the implementation of good governance. Bureaucratic officials still practices to bad governance. The reason is because these parties "enjoy" bad governance. They benefit from a state that is not good.

Another fact, in 2010 the government allocated a total budget of free health program of 240 billion. However, the budget allocation in 2009 there are still districts/cities that do not meet its obligations to realize budget $60 \%$ of total health care costs so that the total health budget is free only to rely on funding from the province. Sinjai 
regency is just one example of the district who reject free health program for their region has been running the program through the regional health insurance. Though owned regional health insurance which are internal only applies only when patients seek treatment at health providers in the district of Sinjai regency. When patients are referred for treatment outside Sinjai regency, automatically be borne by the provincial government that has been allocated by $40 \%$.

This happens because the "plan of good governance" is not prepared properly. By the definition of good governance have not prepared a plan, socialized to all elements of public servants, the preparation is incomplete and inaccurate thus be a plan that has not been good, even tend to provide opportunities for multiple interpretations among government or city government. To overcome this difficult hurdle, all public entities in direct contact with health services free of charge to apply "Open Government Partnership", openness to the public administration. The community also overcome difficult obstacles. With the principle of "Open Government Partnership (OGP)".

\subsection{Change Management}

Changing the mindset of people is a long process, it requires a strong effort and continually in a process called re-forming themselves. Bureaucratic reform began with the reform of the individual, and needs the support levers of change which encourages others to reform themselves. Changes a system could take place when supported by a change in the mindset of people who support and run the system in question. Changes to the mindset of people who support and run the system in question. Changes to the mindset of people and not just limited to changing behavior, which could be only temporary and in the form of affectation, but a shift in perspective (mind set) someone who can last long.

Research results Research and Development Board of South Sulawesi in collaboration with the Institute of Research and Community Service Hasanuddin University. The experiment was conducted at four hospitals namely General Hospital Sulthan Dg. Radja Bulukumba, General Hospital Labuang Baji Makassar, Makassar Power General Hospital and General Hospital Andi Makkasau Pare Pare. In the study found that patients should not be a free health program participants, turned out to take advantage of free health care, and the more interesting is the indication of the involvement of hospital staff and the local government in the phenomenon.

Difficult to change the mindset of the people and interest groups of the case, these changes must be thorough, from top to bottom, and it does not end there, but changes below should provide benefits to the community. Changes that took effect on society is when the policy is implemented properly. In fact, the results also showed that they found a doctor prescribe medicine patents that are supposed to use generic drugs, financial administrative records that are not standard, and the lack of cleanliness of the bathroom floor and bedspreads.

Therefore, management of change as a planning process that acts to improve the system consistently and sustainably has not reached expected goals by the free health care system. Directions for the management of change is the un-expected, the incongruity, the innovation process based on need, changes in industry structure or market structure, demographics, changes in mood and meaning of perception, and new knowledge.

\subsection{Best Value}

Gives the best value realized through best service. The best value is a framework to ensure that the government units that provide free health services to the community has been meeting the needs of society, and focused on efficiency and good governance. The framework appreciate the level of autonomy given to the work units. Although the best value requires that the function was organized as possible, best value does not intervene in the work process.

Best value at the level of free health care has been stated in the Governor Regulation No. 15 Year 2008 on regiona-lization system referral hospital in the province of South Sulawesi. Of the 24 district is divided into six regions, namely; eastern region centered at the General Hospital Sawerigading Palopo, northern region centered at the General Hospital Andi Makkasau Parepare, southeast region centered at the General Hospital Tenriawaru Bone district, the southern region centered on General Hospital A Sulthan Dg. Radja Bulukumba, south gate region centered at the General Hospital La waste Baji Makassar City, and northern gate region centered at Southwestern General Hospital Makassar. With the division of this region is expected to help meet community needs quickly.

Some of the advantages of a framework approach best value with the division of the region. Firstly, the hope is connected directly with the efficiency and at the same time "good governance". Second, the best value approach implemented at various work units in health and local government agencies and even the condition of each unit is different. Third, through a best value approach, there is a raft of performance interactive consultation between 
the parties to serve and those who served in accordance with the principles of the Open Government Partnership. Fourth, the community or communities served by each unit of service providers get public services at the best value (best value customers), because this approach emphasizes the benefit, not a cost. Fifth, the accountability of the service unit will increase. Best value helps the public wants accountability report. Sixth, the best value approach to stimulate the growth of new ideas or innovations that are useful for public service providers and recipients of public services.

The main focus is to implement the six principles consistently best value in every aspect of public management. Therefore, all public officials do not understand and have not yet developed the principle of best value for improving public services with best value principles. Then there has been no effort gradually, by the principle of best value integrated in laws and regulations, especially regulations governing district health services free of charge.

\subsection{Minister as a Public Servant}

Minister and ministry as a public servant and help public services. As has been stated in the Preamble of the 1945 Constitution that the purpose of the State Government of Indonesia is to assist communities in achieving well-being, providing protection services and services to achieve the life and ministry in the world follow the implementation of the order.

Including the appointment of ministers for the purpose of serving the public. However, the fact that the health mi-nister the task directly to the airport agency or local government agencies are expected to provide the best service to the community. Evidence of the Indonesian Health Ministry's decision No. 129 of 2008 on Minimum Service Standards Hospital has given a fresh breeze on the acceleration of free health program. Similarly, in 2011, South Sulawesi gets 9 billion a health funds will be given to each community health center for each of 100 million rupiah.

Minister as a public servant in this case shows that there has been political will from the central government to run a public service to the world-class public management. The question then is to what extent the readiness of local gov-ernment bureaucracy and red tape in the health ministry to interpret it.

Reform of the bureaucracy is still accustomed to using the behavioral pattern of the implementation of free health services refers to the availability of the budget. Public services can only be fulfilled if there is availability of funds for disbursement are experiencing delays.

\subsection{Strategic Plan}

Senior officials have devised a strategic plan to implement the individual as an official agency strategic plan has been implemented in all hospitals as the reference area free health care program. The strategic plan outlined in the draft vision and mission hospitals are mounted on each strategic place.

Strategic plan has been supported form of regulation is regulation Governor Number 13 Year 2008 on Guidelines Program Health Services Guide In the province of South Sulawesi, Governor Regulation No. 15 Year 2008 regarding regionalization Referral System in South Sulawesi Province, and local regulations No. 2 of 2009 on cooperation organizing free health care.

In relation to research in South Sulawesi Provincial Health Office (28 to 30 April 2001) and the Hospital Wahidin Sudirohusodo (1-3 May 2001) some of the provisions of the strategic plan is not running, such as budgets, expendi-tures mechanisms, implementation, supervision, monitoring, database, and the data collection program.

In budgeting for instance affirmed the strategic plan that the free health care carried out by the cooperation between the provincial government and local governments and other third parties such as health authorities and health insurance (BPJS). Thus the obvious source of funding comes from the local government, in fact in the mechanism, local governments have constraints budget provision.

At the position of the provincial government bureaucracy has developed a good strategic plan with legislation that is clear and detailed. So that the behavior of the provincial government bureaucracy can be classified missionary behavior that aims to improve access in order to achieve the optimal level of public health and improve the quality and equity to get services that ease the burden of residents in care financing. On the other hand, the implementation of which was charged to the district government and implementing health services at the hospital are more likely type of political behavior, it is characterized by their readiness to accept the division of their budgets although overwhelmed 40:60 prepare a budget. So it seems only to maintain power or seeking power elsewhere. 


\subsection{Apparatus Professional}

The three regulations or the strategic plan emphasizes that free health care are all basic health services from community health centers (puskesmas) and network and referral health services in three hospitals class of local government, which is free of charge and a drug administered using generics. From the field observations, research at the Hospital Andi Makkasau (May $1 \mathrm{~s} / \mathrm{d}$ May 7, 2013), turned out to patients in the referral of third grade, less attention services by nurses and doctors only occasionally do a check up on every patient who accumulate because the reference is too much of the county hospital. Less use of a prescription with a generic drug, so the drug may not be free because they have bought in private pharmacies which are outside the area of the hospital.

\section{Conclusion}

Based on the results of the discussion, it can be arranged several conclusions as follows: The behavior of the bu-reaucracy in the reform of the bureaucracy to the public management of world-class free health services tend to be the type of politician, this is caused by the tendency of the behavior of officials who organization maintain power and seek power outside the organization, Basic Behavior Service officials are still not applicable in everyday life, especially at the lower levels of the bureaucracy. Learning from Difficult Obstacles still not optimal. Management Changes have not been properly socialized so that tends to maintain old habits. Best value in the service they belong to the bureaucrats are not distributed equitably to the community it serves. Minister as a public servant has issued regulations in order to provide the best service. The strategic plan of the provincial government has not been implemented at the level of the county or city. Apparatus professionals have yet to implement the principles of professionalism. Thus emphasized that this type of bureaucratic behavior in order to reform the bureaucracy toward a world-class public management is the type of politician.

\section{References}

Adler, P., \& Borys, B. (1996). Two Types of Bureaucracy: Enabling and Coercive. Administrative Science Quarterly, 41(1), 61-89. https://doi.org/10.2307/2393986

Ahmad, J. (2011). Perilaku Birokrasi dan Pengambilan Keputusan. Makassar: Badan Penerbit UNM.

Ajzen, I. (1991). The Theory of Planned Behavior. Organizational Behavior and Human Decision Processes, 50, 179-211. https://doi.org/10.1016/0749-5978(91)90020-T

Alesina, A., \& Guido, T. (2007). Bureaucrats or Politicians? Part I: A Single Policy Task. American Economic Review, 97, 169-179. https://doi.org/10.1257/000282807780323578

Bryant, C., \& Louise, G. W. (1989). Manajemen Pembangunan Untuk Negara Berkembang. Jakarta: LP3ES.

Donelly, R. (2009). Career behavior in the knowledge economy: Experiences and perceptions of career mobility among management and IT consultants in the UK and the USA. Journal of Vocational Behavior, 75(3), 319-328. https://doi.org/10.1016/j.jvb.2009.04.005

Downs, A., \& Rand Corporation. (1967). Inside bureaucracy (p. 264). Boston: Little, Brown.

Dwiyanto, A. (2002). Reformasi Pelayanan Publik. Policy Brief. Yogyakarta: Center for Population and Policy Studies, Universitas Gajah Mada.

Etzioni, A. (1961). A Comparative Analysis of Complex Organizations. New York: Free Press.

Evans, T. (2016). Professional discretion in welfare services: Beyond street-level bureaucracy. Routledge.

Keiser, L. R. (2010). Understanding Street-Level Bureaucrats' Decision Making: Determining Eligibility in the Social Security Disability Program. Public Administration Review, 70, 247-257. https://doi.org/10.1111/j.1540-6210.2010.02131.x

Perry, J., \& Wise, L. (1990). The Motivational Bases of Public Service. Public Administration Review, 50(3), 367-373. https://doi.org/10.2307/976618

Plastrik, P., \& David, O. (1997). Banishing Bureaucracy: The Five Strategies For Reinventing Government. Massachusetts: Addison-Wesley, Reading.

Riggs, F. W. (1986). Administrasi Pembangunan. Jakarta, Rajawali.

Riggs, F. W. (1994). Administrasi Pembangunan Sistem Administrasi dan Birokrasi. Jakarta: PT Raja Grafindo Persada.

Robbins, S. P., \& Judge, T. A. (1993). Organization behaviour. London: Prentice Hall. 
Said, M. (2007). Birokrasi di Negara Birokrasi. Malang: UPT, Publishing University of Malang.

Schmidt, C. P. (2000). Changing Bureaucratic Behavior. United States: Personnel management.

Siagian, S. P. (1994). Patologi Birokrasi, Analisis, Identifikasi dan Terapinya. Jakarta: Ghalia Indonesia.

Thompson, V. (1965). Bureaucracy and Innovation. Administrative Science Quarterly, 10(1), 1-20. https://doi.org/10.2307/2391646

Winter, S. C. (2002, August). Explaining street-level bureaucratic behavior in social and regulatory policies. In Annual meeting of the American Political Science Association in Boston (Vol. 29).

\section{Copyrights}

Copyright for this article is retained by the author(s), with first publication rights granted to the journal.

This is an open-access article distributed under the terms and conditions of the Creative Commons Attribution license (http://creativecommons.org/licenses/by/4.0/). 